\title{
Oxidative stability of refrigerated fish pates containing loquat seed extract
}

\author{
Estabilidade oxidativa de patês de pescado contendo extrato \\ de semente de nêspera armazenados refrigerados
}

\author{
Jaqueline Piccolo $^{\mathrm{I}^{*}}$ Ana Paula Daniel ${ }^{\mathrm{III}}$ Bruna Klein $^{\mathrm{I}}$ Lauren Fresinghelli Ferreira ${ }^{\mathrm{III}}$ \\ Amanda Roggia Ruviaro ${ }^{I}$ Tatiana Emanuelli ${ }^{I}$ Ernesto Hashime Kubota ${ }^{I}$
}

\section{ABSTRACT}

This study investigated the effects of hydroethanolic E. japonica seed extracts (EJSE) as inhibitors of lipid and protein oxidation on fish pates subjected to refrigerated storage. Five fish pate formulations were developed. These formulations included two control pates (water-control and ascorbic acid-control) and three pates with added EJSE (0.1, 0.2 and $0.4 \mathrm{~g}$ of seed $100 \mathrm{~g}^{-1}$ product, equivalent to 3.4, 6.8 or $13.6 \mathrm{mg}$ phenolic compounds $\mathrm{kg}^{-1}$ product), which were then stored under refrigeration for 35 days. Conjugated dienes $(C D)$ and peroxide $(P V)$ values increased along with the storage time; however, these values decreased and were similar among all samples at the end of 35 days of analysis $(P<0.05)$. However, the thiobarbituric acid reactive substances levels (TBARS) did not change along the storage and were not affected by the EJSE. Additionally, there was a linear increase in the protein carbonyl content of fish pates over the storage period $(P<0.05)$, but no effect of EJSE on protein oxidation. The results show that, at the concentrations evaluated, hydroethanolic $\boldsymbol{E}$. japonica seed extract was unable to inhibit or reduce lipid and protein oxidation in fish pates, but the observed phenolic content emphasizes the need for further studies on the wastes of this fruit.

Key words: Eriobotrya japonica, Rhamdia quelen, lipid oxidation, protein oxidation, wastes.

RESUMO

Este trabalho investigou os efeitos do extrato hidroetanólico de semente de E. japonica (EJSE) como inibidor da oxidação lipídica e proteica em patês a base de pescado armazenados refrigerados. Foram desenvolvidas cinco formulações de patê de pescado. Estas formulações incluíram dois patês controles (controle-água e controle-ácido ascórbico) $e$ três adicionados de EJSE $\left(0,1 ; 0,2\right.$ e 0,4g de semente $100 \mathrm{~g}^{-1}$ de produto, equivalente a 3,4; 6,8 ou 13,6mg compostos fenólicos $\mathrm{kg}^{-1}$ de produto) que foram armazenados refrigerados durante
35 dias. Os valores de dienos conjugados $(C D)$ e peróxidos (PV) aumentaram ao longo do armazenamento, contudo, $C D$ e $P V$ diminuíram de maneira semelhante em todas as amostras aos 35 dias de análise $(P<0,05)$. No entanto, o conteúdo de substâncias reativas ao ácido tiobarbitúrico (TBARS) não se modificou ao longo do armazenamento e não foi afetado pelo EJSE. Também houve aumento linear no conteúdo de proteínas carboniladas dos patês de pescado ao longo do armazenamento $(P<0,05)$, sem efeito do EJSE na oxidação proteica. Os resultados mostram que, nas concentrações avaliadas, o extrato hidroetanólico de semente de E. japonica não foi capaz de inibir ou reduzir as oxidações lipídicas e proteicas em patês de pescado, mas seu conteúdo fenólico enfatiza para a necessidade de aprofundar as pesquisas com o resíduo desta fruta.

Palavras-chave: Eriobotrya japonica, Rhamdia quelen, oxidação lipídica, oxidação proteica, resíduos.

\section{INTRODUCTION}

Lipid oxidation is the main cause of muscle food quality deterioration. It is a complex process in which unsaturated fatty acids react with molecular oxygen to generate a free radical chain mechanism, creating fatty acid hydroperoxides, which are the primary products of the oxidation and initiate the oxidative chain (GRAY, 1978). In addition, compounds resulting from lipid oxidation can modify proteins, inducing crosslinking and resulting in undesirable changes in food properties, including protein denaturation, loss of protein solubility, changes in the texture and functional properties of

\footnotetext{
IPrograma de Pós-graduação em Ciência e Tecnologia dos Alimentos, Centro de Ciências Rurais (CCR), Universidade Federal de Santa Maria (UFSM), 97105-900, Santa Maria, RS, Brasil. Email: jaquelinepiccolo@gmail.com. *Autor para correspondência.

IIColégio Politécnico, UFSM, Santa Maria, RS, Brasil.

IIICurso Superior em Farmácia, Centro de Ciências da Saúde (CCS), UFSM, Santa Maria, RS, Brasil. 
proteins and destruction of nutrient components (VERMA et al., 1995).

Fish are an important source of protein and contain high levels of n-3 polyunsaturated fatty acids (PUFA). The consumption of these fatty acids is involved in brain development of children and protection against cancer, heart disease, diabetes and mental illness (ZAMARIA, 2004). Despite the benefits of PUFAs, they are highly susceptible to oxidation due to their double bonds. The oxidation of lipids leads to discoloration, unpleasant odor and rancid taste (FRANKEL, 2005). In addition, lipid oxidation can accelerate the oxidation of proteins, which results in texture and technological changes in the product (XIONG, 2000).

Thus, the increase in the number of healthconcerned consumers and the increased demand for fish products due to their health benefits have motivated the development of new seafood products with longer shelf lives using natural antioxidants. Waste products from fruits and vegetables offer an economical source of antioxidants that could replace synthetic molecules.

Loquat (Eriobotrya japonica) is an Asian fruit that is native to Japan and cultivated in various other tropical and subtropical countries (FEMENIA et al., 1998). Recent studies reveal that loquat seeds have the highest polyphenol content and show the most potent activity against lipid oxidation (KOBA et al., 2007). In addition, the methanol and ethanol extracts of loquat seed inhibited hepatic fibrosis in rats (NISHIOKA et al., 2002). Moreover, there has been no study on the antioxidant potential of extracts from loquat seeds against lipid oxidation in food systems, which would be an interesting use for this product. In this context, the assessment of the potential of loquat seeds to prevent the oxidation of food products has merit. The aim of this research was to investigate the effect of the addition of hydroethanolic extracts of seeds from $\boldsymbol{E}$. japonica on lipid and protein oxidation of fish pates during refrigerated storage.

\section{MATERIALS AND METHODS}

\section{Preparation of extracts}

The loquat fruits (E. japonica) were collected from native plants in the Santa Maria region of Rio Grande do Sul state, Brazil. Ten grams of ground seeds (without the dark coat) were homogenized in approximately $70 \mathrm{ml}$ of $80 \%$ ethanol. The homogenate was then incubated at $50^{\circ} \mathrm{C}$ for $30 \mathrm{~min}$ and then cooled to room temperature. The homogenate was centrifuged at $1083.1 \times \mathrm{g}$ for 3min and filtered into a volumetric flask. The extracts were re-suspended in $80 \%$ ethanol to the proper volume (100ml) and stored at $-18^{\circ} \mathrm{C}$ until analysis. The total phenolic compound contents of three independent extracts were evaluated according to the method of SINGLETON \& ROSSI (1965), with some modifications. The phenolic content of the extracts was $339.9 \pm 14.2 \mathrm{mg}$ gallic acid $\mathrm{l}^{-1}$ (equivalent to $339.9 \pm 14.2 \mathrm{mg}$ gallic acid $100 \mathrm{~g}^{-1}$ seed).

Preparation of filleting waste pulp and fillets of fish Fresh silver catfish (Rhamdia quelen) were obtained from a local market, washed in cold water with 5ppm chlorine, beheaded, gutted, and filleted. The ventral muscles and backbone (without fins) were treated as residues of the filleting process and used to prepare the filleting waste pulp as described by BOCHI et al. (2008). Fillets and filleting waste pulp were packed and kept at $-18^{\circ} \mathrm{C}$ until use (approximately 7 days).

\section{Manufacture of fish pate formulations}

Five formulations were developed including a negative control containing distilled water, a positive control containing ascorbic acid ( $0.02 \mathrm{~g}$ of ascorbic acid $100 \mathrm{~g}^{-1}$ of product) and three formulations with increasing amounts of the hydroethanolic extract to yield $3.4,6.8$ or $13.6 \mathrm{mg}$ phenolic compounds $\mathrm{kg}^{-1}$ product $(0.1,0.2$ and $0.4 \mathrm{~g}$ of seed $100 \mathrm{~g}^{-1}$ of product).

The control formulation had the following ingredients per $\mathrm{kg}$ of batter: $280 \mathrm{~g}$ fish fillet, $260 \mathrm{~g}$ fish pulp, $200 \mathrm{ml}$ cold water, $200 \mathrm{ml}$ soybean oil, $15 \mathrm{~g}$ soybean isolate protein, $20 \mathrm{~g}$ starch, $18 \mathrm{~g}$ salt, $6 \mathrm{~g}$ seasoning mix, $2 \mathrm{~g}$ garlic, $1.5 \mathrm{~g}$ sodium nitrite, $2 \mathrm{~g}$ sodium tripolyphosphate, $2 \mathrm{ml}$ liquid smoke, and $2 \mathrm{ml}$ carmine coloring. Sodium erythorbate was not used in the formulations (except for the positive control containing ascorbic acid) so that the color and oxidation parameters were not influenced. In fish pates treated with the extract, the water was replaced with hydroethanolic extract, whereas the other ingredients were the same in controls and treated pates. All of the ingredients were minced in a cutter, transferred into artificial casings, cooked at $74-76^{\circ} \mathrm{C}$, cooled with cold water $\left(5^{\circ} \mathrm{C}\right)$, and dried and stored at $5 \pm 1^{\circ} \mathrm{C}$ for shelf life analysis. The lipid and protein oxidation were assessed after 1, 9, 15, 21 and 35 days of storage. Three independent replicates were prepared for each fish pate formulation for each day of evaluation and were analyzed in duplicate. 
Lipid oxidation

The fat was extracted using chloroform and methanol as described by BLIGH \& DYER (1959) to determine the fat content. The conjugated dienes (CD) and peroxide values (PV) were determined in the extracted fat by the BLIGH \& DYER method (1959). Cyclohexane was used as the solvent, and the optical density was recorded at 233nm for the determination of CD (RECKNAGEL \& GLENDE, 1984). All measurements were normalized to a uniform base of $1 \mathrm{mg}$ lipid/ml of cyclohexane. The PV was determined using a ferric thiocyanate method according to CHAPMAN \& MACKAY (1949). A standard curve generated using ferric iron solutions was used to calculate the peroxide contents of the fat.

Thiobarbituric acid reactive substances (TBARS) were determined spectrophotometrically as described by BUEGE \& AUST (1978). The samples were homogenized with $1.5 \% \mathrm{KCl}$, and the supernatant was incubated at $100^{\circ} \mathrm{C}$ for $15 \mathrm{~min}$ in a medium containing trichloroacetic acid (TCA) and thiobarbituric acid. After incubation, butyl alcohol was used to extract the reaction product, which was measured at $535 \mathrm{~nm}$.

\section{Protein oxidation}

Protein oxidation was assessed based on the amount of protein carbonyl groups as described by LEVINE et al. (1994). The samples (1g) were homogenized in phosphate-buffered saline (PBS) (4ml), precipitated with TCA, and incubated with dinitrophenylhydrazine in the dark for $15 \mathrm{~min}$. Then, samples were precipitated with TCA, and the pellets were washed with 1:1 (v/v) ethanol/ethyl acetate. The pellet was re-dissolved in $2 \%$ sodium dodecyl sulfate (SDS), and the carbonyl content was determined by measuring the absorbance at 370nm. The results are expressed in nmoles carbonyl per mg of protein.

\section{Statistical analysis}

All analyses were run in duplicate, and the results were expressed as the mean \pm standard deviation (SD). The lipid and protein oxidation were evaluated using two-way factorial ANOVA (5 formulations $\times 5$ storage times). Post-hoc comparisons were made using Tukey's test $(\mathrm{P}<0.05)$. The statistical analysis was conducted using the Statistica software package version 6.0 (Copyright StatSoft, Inc. 1984-2001).

\section{RESULTS AND DISCUSSION}

The results of the analysis of the lipid and protein oxidation from fish pates containing loquat seed extract during refrigerated storage are shown in figure 1 and table 1. Lipids containing methyleneinterrupted dienes or polyenes show a shift in the position of the double bond during the oxidation due to isomerization and the formation of CD. The formation of $\mathrm{CD}$ is reported to increase with the uptake of oxygen during the early stages of oxidation and to result in the formation of primary oxidation products, along with the peroxides (HALLIWELL \& GUTTERIDGE, 1989).

Our results indicated an interaction between the treatment and storage time effects on the CD values of the fish pates (Figure 1A). The CD values increased during the storage period; however, this increase on the $9^{\text {th }}$ and $15^{\text {th }}$ days of storage was less pronounced for the EJ-0.4g\% formulation, which had lower CD values compared to the $\mathrm{W}$-control $(\mathrm{P}<0.05)$. On the $15^{\text {th }}$ day of storage, all formulations had lower CD values than the $\mathrm{W}$-control $(\mathrm{P}<0.05)$. The CD values of EJ-treated pates were similar to those found in the W-control at 1, 21 and 35 days of refrigerated storage.

The concentration of hydroperoxides formed during PUFA oxidation is used as a measure of the extent of oxidation. There was an interaction between the treatment and storage time effects on the peroxide value (PV) of fish pates (Figure 1B). The PV increased greatly over 21 days of storage only for the EJ-treated pates, which also had higher PV than the AA-control and $\mathrm{W}$-control at 21 days of storage $(\mathrm{P}<0.05)$. However, the $\mathrm{PV}$ were similar among all samples on the $35^{\text {th }}$ day of storage.

Thereby, the lower CD levels found in EJtreated pates compared to $\mathrm{W}$-control on the $15^{\text {th }}$ day of analysis may be associated to the higher PV levels of EJtreated pates on the $21^{\text {st }}$ day of analysis (Figure 1), since conjugated dienes are converted to hydroperoxides in the lipid oxidation chain (GRAY, 1978). These results indicate that the progress of lipid oxidation was faster in the EJ-treated pates compared to the controls.

Secondary lipid oxidation was studied based on the TBARS value, which is an index of malonaldehyde (MDA) concentration. MDA is one of the main end products of lipid oxidation. The TBARS values showed no significant changes during storage time $\left(0.04 \pm 0.04 \mathrm{mg} \mathrm{MDA} \mathrm{kg}^{-1}\right.$ pate at day 1 and $0.04 \pm 0.03 \mathrm{mg} \mathrm{MDA} \mathrm{kg}^{-1}$ pate at 35 days of refrigerated storage). In addition, EJ extract did not change TBARS values of pates (data not shown). This finding contrasts with the study by KOBA et al. (2007), where the ethanol extract of loquat seed significantly lowered TBARS levels and showed an inhibitory effect on LDL oxidation in vitro. However, in our study, despite the moderate temperature 


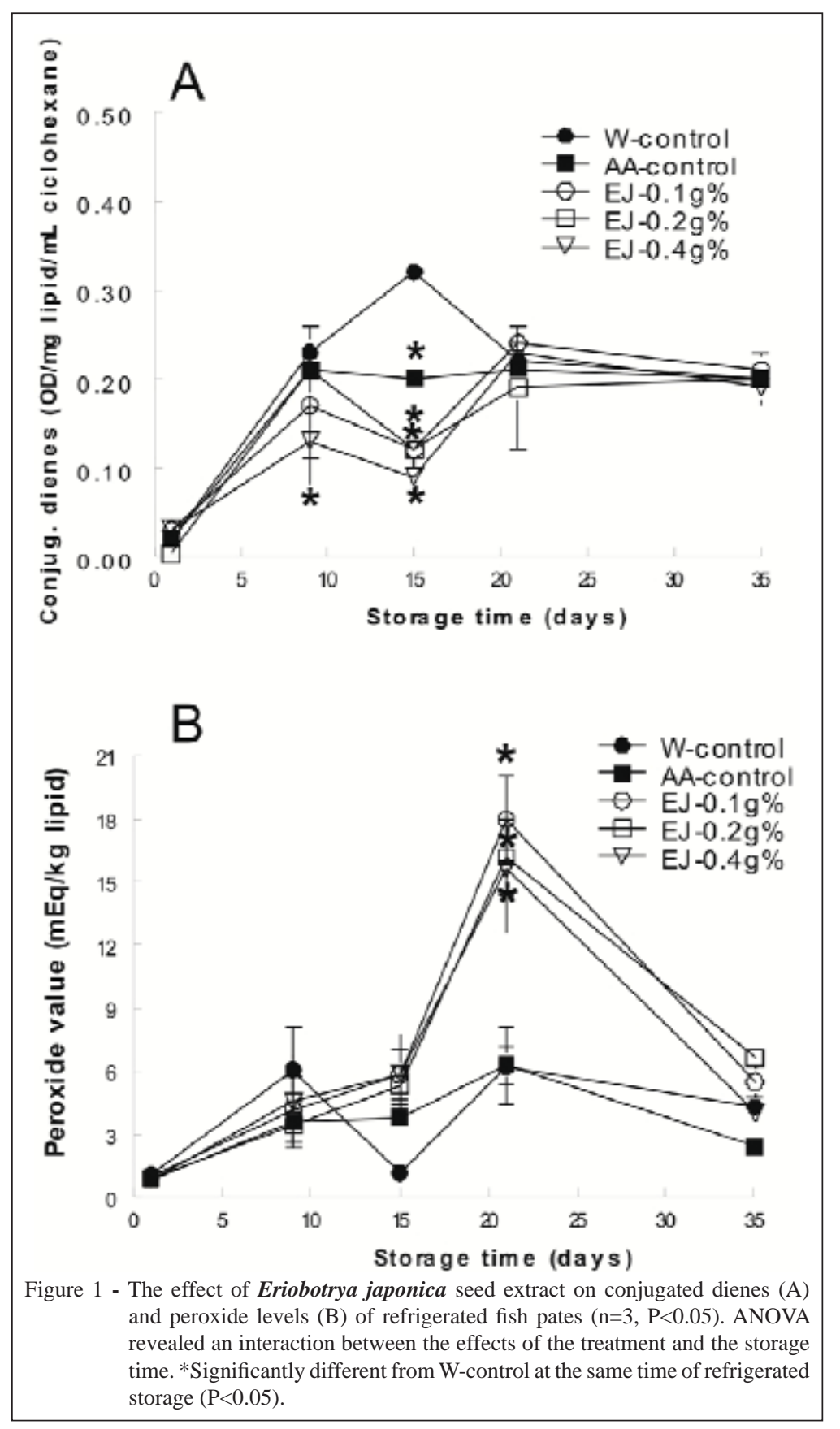

employed in the cooking of fish pates and its potential to initiate lipid oxidation, there was no increase in the TBARS value during the storage, which indicates that no appreciable amount of secondary lipid oxidation products was formed during the storage. Therefore, our TBARS results suggest that the storage time was not sufficiently long to produce secondary lipid oxidation products in the fish pates.

In contrast, there was a decrease in PV of EJ-treated pates, which indicates the degradation of these primary compounds into secondary ones. Because TBARS levels did not increase, we suggest that hydroperoxides may have been degraded into compounds that cannot be detected in the TBARS assay, such as ketones, alcohols, aldehydes (except MDA), hydrocarbons, volatile organic acids or epoxy compounds (SHAHIDI \& ZHONG, 2010).

Therefore, the decrease in hydroperoxides with unchanged levels of TBARS in fish pates suggests that lipid oxidation is either in the initial 
Table 1 - Effect of Eriobotrya japonica seed extract on the protein carbonyl content (nmol mg ${ }^{-1}$ protein) of refrigerated fish pates.

\begin{tabular}{|c|c|c|c|c|c|c|}
\hline \multirow{2}{*}{ Storage time } & \multicolumn{5}{|c|}{ 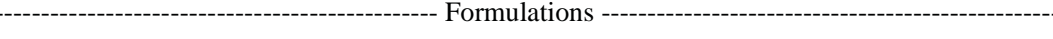 } & \multirow{2}{*}{ Average } \\
\hline & W-control & AA-control & EJ-0.1g\% & $\mathrm{EJ}-0.2 \mathrm{~g} \%$ & EJ-0.4g\% & \\
\hline Day 1 & $3.6 \pm 0.4$ & $1.8 \pm 0.8$ & $3.7 \pm 1.5$ & $4.4 \pm 0.3$ & $4.0 \pm 0.6$ & $3.5 \pm 1.1^{\mathrm{d}}$ \\
\hline Day 9 & $5.7 \pm 1.0$ & $4.8 \pm 0.9$ & $4.7 \pm 0.8$ & $4.8 \pm 1.8$ & $7.7 \pm 0.9$ & $5.6 \pm 1.5^{c}$ \\
\hline Day 15 & $5.6 \pm 4.3$ & $5.1 \pm 1.4$ & $8.9 \pm 1.3$ & $5.5 \pm 0.3$ & $7.9 \pm 0.9$ & $6.6 \pm 2.3^{\mathrm{bc}}$ \\
\hline Day 21 & $7.8 \pm 0.8$ & $9.4 \pm 2.6$ & $8.1 \pm 2.4$ & $7.6 \pm 1.0$ & $7.2 \pm 1.9$ & $8.1 \pm 1.8^{\mathrm{ab}}$ \\
\hline Day 35 & $8.8 \pm 4.6$ & $11.8 \pm 2.7$ & $8.6 \pm 0.6$ & $7.7 \pm 0.6$ & $7.5 \pm 0.3$ & $9.1 \pm 2.7^{\mathrm{a}}$ \\
\hline
\end{tabular}

Values for each formulation are mean \pm standard deviation of 3 replicates, whereas the average values of all formulations are mean \pm standard deviation of 15 replicates. ANOVA revealed a significant effect of storage time but no effect of treatment. Values with different superscript in a column differ significantly $(\mathrm{P}<0.05)$.

stage or yielded secondary oxidation products that cannot be detected in the TBARS tests.

The protein oxidation in the fish pates was evaluated based on the formation of protein carbonyl groups (Table 1). Oxidative reactions involving the side chains of amino acids can lead to the formation of carbonyl groups, which may result in an increased susceptibility to protein aggregation and a loss of solubility, leading to a loss of quality (STADTMAN, 1990). There was a linear increase in the protein carbonyl content of fish pates over the storage period, but no difference between the formulations (Table 1; $\mathrm{P}<0.05$ ). Thus, no beneficial effect of EJ extract was observed on the protein oxidation.

Proteins can be modified by compounds resulting from the lipid oxidation, leading to amino acid changes and a decrease in protein functionality (LUND et al., 2011). Also, proteins can be modified independently of lipids and may be modified by reactive oxygen species (ROS), which include free radicals but also by non-radical species such as hydrogen peroxide and hydroperoxides. This was most likely what occurred in our study; we detected an increase in protein oxidation and no increase in secondary lipid oxidation products (TBARS) during storage. Thus, the high concentration of proteins and their proximity to hydroperoxides in this food product could have exposed proteins to oxidative reactions.

Furthermore, several studies show no effect of phenolic-containing plant extracts on the formation of protein carbonyl groups during heat treatment of meat products (ESTÉVEZ et al., 2006). This occurs because the protective effect is dependent on the composition of the raw material (meat as well as antioxidants), antioxidant concentration and production technology used (JONGBERG et al., 2013).

\section{CONCLUSION}

E. japonica seed extract, at the concentrations tested was not effective to prevent lipid or protein oxidation in fish pates. More studies are necessary to enhance the antioxidant potential of this product in fish pates and explore this waste vegetable source as a natural antioxidant.

\section{ACKNOWLEDGEMENTS}

This work was supported by fellowships from the Coordination for the Improvement of Higher Education Personnel (Capes) and National Council for Scientific and Technological Development $(\mathrm{CNPq})$, and financial support from $\mathrm{CNPq}$ 552440/2011-6.

\section{REFERENCES}

BLIGH, E.G.; DYER, W.J. A rapid method of total lipid extraction and purification. Canadian Journal of Biochemistry Physiology, v.37, n.8, p.911-917, 1959. Available from: <http://www.nrcresearchpress.com/doi/abs/10.1139/o59099?journalCode=cjbp\#.Ugjnt5KceSo>. Accessed: Jan. 03, 2011. doi: 10.1139/o59-099.

BOCHI, V.C. et al. Fishburgers with silver catfish (Rhamdia quelen) filleting waste. Bioresource Technology, v.99, p.88448849, 2008. Available from: <http://www.sciencedirect.com/ science/article/pii/S0960852408004148>. Accessed: Apr. 23, 2013. doi: 10.1016/j.biortech.2008.04.075.

BUEGE, J.A.; AUST, S.D. Microsomal lipid peroxidation. Methods in Enzymology, v.52, p.302-310, 1978. Available from: <http:// www.sciencedirect.com/science/article/pii/S0076687978520326>. Accessed: Nov. 11, 2012. doi: 10.1016/S0076-6879(78)52032-6.

CHAPMAN, R.A.; MACKAY, K. The estimation of peroxides in fats and oils by the ferric thiocyanate method. Journal of the American Oil Chemists'Society, v.26, p.360-363, 1949. Available from: <http://link.springer.com/article/10.1007\%2FBF02651444>. Accessed: Jul. 14, 2012. doi: 10.1007/BF02651444. 
ESTÉVEZ, M. et al. Effect of natural and synthetic antioxidants on protein oxidation and colour and texture changes in refrigerated stored porcine liver pâté. Meat Science, v.74, n.2, p.396-403, 2006. Available from: <http://www.sciencedirect.com/science/ article/pii/S0309174006001124>. Accessed: Apr. 12, 2013. doi: 10.1016/j.meatsci.2006.04.010.

FEMENIA, A. et al. Characterization of the cell walls of loquat (Eriobotrya japonica L.) fruit tissues. Carbohydrate Polymers, v.35, n.3-4, p.169-177, 1998. Available from: <http://www. sciencedirect.com/science/article/pii/S0144861797002403>. Accessed: Dec. 06, 2012. doi: 10.1016/S0144-8617(97)00240-3.

FRANKEL, E.N. Lipid oxidation. 2.ed. Bridgwater: The Oily, 2005. 470p.

GRAY, J.I. Measurement of lipid oxidation: a review. Journal of the American Chemical Society, v.55, n.6, p.539-546, 1978. Available from: <http://link.springer.com/ article/10.1007\%2FBF02668066>. Accessed: Apr. 12, 2013. doi: 10.1007/BF02668066.

HALLIWELL, B.; GUTTERIDGE, J.M.C. Free radicals in biology and medicine. Oxford: Clarendon, 1989. 543p.

JONGBERG, S. et al. Effect of green tea or rosemary extract on protein oxidation in Bologna type sausages prepared from oxidatively stressed pork. Meat Science, v.93, p.538-546, 2013. Available from: <http://www.sciencedirect.com/science/article/pii/ S030917401200366X>. Accessed: Jun. 23, 2012. doi: 10.1016/j. meatsci.2012.11.005.

KOBA, K. et al. Effect of loquat (Eriobotrya japonica) extracts on LDL oxidation. Food Chemistry, v.104, n.1, p.308-316, 2007. Available from: <http://www.sciencedirect.com/science/article/pii/ S0308814606009216>. Accessed: Jan. 18, 2012. doi: 10.1016/j. foodchem.2006.11.043.

LEVINE, R.L. et al. Carbonyl assays for determination of oxidatively modified proteins. Methods in Enzymology, v.233, p.346-357, 1994. Available from: <http://www.sciencedirect.com/ science/article/pii/S0076687994330409>. Accessed: Sept. 19, 2012. doi: 10.1016/S0076-6879(94)33040-9.

LUND, M. et al. Protein oxidation in muscle foods: a review. Molecular Nutritional Food Research, v.55, p.83-95, 2011. Available from: <http://onlinelibrary.wiley.com/doi/10.1002/ mnfr.201000453/abstract>. Accessed: Apr. 26, 2013. doi: 10.1002/mnfr.201000453.
NISHIOKA, Y. Effects of extract derived from Eriobotrya japonica on liver function improvement in rats. Biological and Pharmaceutical Bulletin, v.25, n.8, p.1053-1057, 2002. Available from: <https://www.jstage.jst.go.jp/article/bpb/25/8/25_8_1053/_ article>. Accessed: May 28, 2013. doi: 10.1248/bpb.25.1053.

RECKNAGEL, R.O.; GLENDE, E.A.J. Spectrophotometric detection of lipid conjugated dienes. Methods in Enzymology, v.105, p.331-337, 1984. Available from: <http://www. sciencedirect.com/science/article/pii/S0076687984050436>. Accessed: Jun. 12, 2012. doi: 10.1016/S0076-6879(84)05043-6.

SHAHIDI, F.; ZHONG, Y. Lipid oxidation and improving the oxidative stability. Chemical Society Reviews, v.39, n.11, p.40674079, 2010. Available from: <http://pubs.rsc.org/en/Content/ ArticleLanding/2010/CS/b922183m\#!divAbstract>. Accessed: Nov. 20, 2013. doi: 10.1039/b922183m.

SINGLETON, V.L.; ROSSI, .J.A.J. Colorimetry of total phenolics with phosphomolybdic-phosphotungstic acid reagents. American Journal of Enology and Viticulture, v.16, p.144-158, 1965. Available from: <http://ajevonline.org/content/16/3/144.short>. Accessed: Apr. 08, 2012.

STADTMAN, E.R. Metal ion-catalyzed oxidation of proteins: Mechanism and biological consequences. Free Radical Biology \& Medicine, v.8, n.3, p.315-325, 1990. Available from: <http:// www.sciencedirect.com/science/article/pii/0891584990900065>. Accessed: Jan. 30, 2013. doi: 10.1016/0891-5849(90)90006-5.

VERMA, J. et al. Effects of frozen storage on lipid freshness parameters and some functional properties of oil sardine (Sardinella longiceps) mince. Food Research International, v.28, p.87-90, 1995. Available from: <http://www.sciencedirect. com/science/article/pii/096399699593336S>. Accessed: Feb. 13, 2013. doi: 10.1016/0963-9969(95)93336-S.

XIONG, Y.L. Protein oxidation and implications for muscle food quality. In: DECKER E.A. et al. (Eds.). Antioxidants in muscle foods. New York: Wiley, 2000. p.85-111.

ZAMARIA, N. Alteration of polyunsaturated fatty acid status and metabolism in heatlh and disease. Reproduction Nutrition Development, v.44, n.3, p.273-282, 2004. Available from: <http:// rnd.edpsciences.org/articles/rnd/abs/2004/04/R4012/R4012. html>. Accessed: Feb. 02, 2013. doi: 10.1051/rnd:2004034. 